\title{
NOTES FOR AUTHORS
}

The Journal of Helminthology provides an international vehicle for the publication of original papers and review articles on all aspects of pure and applied helminthology, particularly those helminth parasites of environmental health, medical or veterinary importance. For those wishing to contribute research papers, work on helminths in wildlife hosts including plant and insect parasites will also be welcome. Taxonomic contributions will be acceptable if they contribute to the systematics of a group and particularly if they employ biochemical or molecular biological techniques. Research notes are also included. The Joumal is also produced electronically and is available on the WWW to subscribers.

Page Format. The Journal is printed in a two-column format (column width of $80 \mathrm{~mm}$ ) with a text area of $170 \times 225 \mathrm{~mm}$.

Text. Papers should be typed, on one side of the paper only, with double line spacing and ample margins (at least 1.5 $\mathrm{cm}$ ) on each side and with no underlining or bold in text except for scientific names. Draft quality print from a wordprocessor is not acceptable. Standard abbreviations (e.g. fig. and figs) and metric units must be used. Use British rather than American spellings. Use ' $z$ ' rather than ' $s$ ' spellings in words with 'ize'.

Disks. Upon acceptance, authors are requested to submit a computer disk containing the final version of their paper along with the final manuscript to the editorial office. Please do the following: (1) Label disk clearly with author's name, title of journal and short title of the article; (2) Specify which word processing software (including which version) was used (e.g. WordPerfect 6.0); (3) Specify what computer was used; (4) Include both original file and ASCII file on the disk; (5) Keep a backup disk for reference and safety.

Abstract. Each paper must commence with an accurate, informative abstract in one paragraph, that is complete in itself and intelligible without reference to text or figures. It should not exceed 250 words. A short title should be provided as a running head.

Tables. Tables should be reduced to the simplest form and present only essential data. They should be submitted on separate sheets at the end of the article and must fit into single column, full width or landscape (if absolutely necessary) format. Captions should be typed on a separate sheet. The use of vertical rules should be avoided

Illustrations. Copies of artwork only should be submitted. The original illustrations should accompany the paper after acceptance and revision. Captions should be typed on a separate sheet.

\section{Line drawings}

These should be sharp and clear, black ink on white paper to about 1.5 times the intended final size. The lettering and lines should be of sufficient thickness and quality to stand reduction. Computer generated figures and graphs should not contain grey tints or complicated hatching.

\section{Half-tone photographs}

Black and white half-tone photographs are acceptable where they are a real contribution to the text. They should be prints of good quality at the intended final size with any required lettering or numbering inserted by the author.

Voucher specimens. The deposition of voucher specimens should be considered where appropriate.
References. References must be based on the name and year system, give full journal titles and conform to the following styles:

Bowles, J., Blair, D. \& McManus, D.P. (1995) A molecular phylogeny of the genus Echinococcus. Parasitology 110, 317-328.

Molloy, S., Holland, C. \& O'Regan, M. (1995) Population biology of Pomphorhynchus laevis in brown trout from two lakes in the west of Ireland. Journal of Helminthology 69, 229-235.

Sanderson, C.J. (1993) Cytokines active on eosinophils. pp. 274-283 in Makino, S. \& Fukuda, T. (Eds) Eosinophils: biological and clinical aspects. Boca Raton, CRC Press.

Citation of authors in the text should appear in the form: Polaszek (1996) or (Polaszek, 1996). Authors should be cited in chronological order as: (Blackman et al., 1994; Roberts \& Kumar, 1995).

Proofs. Authors will receive two sets of page proofs. One set is for correcting and should be returned as promptly as possible to the address given, the other set is to be retained.

Voucher copy. A voucher copy of the Journal is provided free to the author (or major author) of each paper.

Offprints. 50 copies of each paper are provided free to the author (or major author) of each paper. Additional copies may be obtained on payment and the number required must be specified and ordered at proof stage, when prices will be quoted. Orders must be received before the issue has gone to press.

Copyright. Authors will be supplied with a copyright form which must be completed and returned to the Publisher Papers are accepted on the understanding that the work has been submitted exclusively to the Journal and has not been previously published elsewhere unless otherwise stated.

Disposal of material. Once published, all copies of the manuscript, correspondence and artwork will be held for six months before disposal. Authors must contact the Editor if they wish to have any material returned.

Manuscripts. Three copies of the manuscript and artwork should be submitted to:

The Editor

Journal of Helminthology

CABI Bioscience UK Centre (Egham)

Bakeham Lane

Egham

Surrey TW20 9TY

UK 


\section{Journal of Helminthology}

Editorial

Symposium Papers

Viney, M.E. Nematode population genetics

Blouin, M.S. Mitochondrial DNA diversity in nematodes.

Roos, M.H., Hoekstra, R., Plas, M.E., Otsen, M. \& Lenstra, J.A. Polymorphic DNA markers in the genome of parasitic nematodes

Galvani, A. \& Gupta, S. The effects of mating probability on the population genetics of nematodes

Kennedy, C.R., Berrilli, F., Di Cave, D., De Liberato, C. \& Orecchia, P. Composition and diversity of helminth communities in eels Anguilla anguilla in the River Tiber: long-term changes and comparison with insular Europe.

Font, W.F. Parasites in paradise: patterns of helminth distribution in Hawaiian stream fishes.

Research Papers

Abrous, M., Comes, A.M., Gasnier, N., Rondelaud, D., Dreyfuss, G., Chauvin, A., Ménard, A., Agoulon, A. \& Cabaret, J. Morphological variability in Fasciola hepatica eggs in ruminants, rodents and lagomorphs.

Davis, N.E. Population dynamics of and larval trematode interactions with Lymnaea tomentosa and the potential for biological control of schistosome dermatitis in Bremner Bay, Lake Wanaka, New Zealand

Ford, D.M., Nollen, P.M. \& Romano, M.A. The effects of salinity, $\mathrm{pH}$ and temperature on the half-life and longevity of Echinostoma caproni miracidia.

Galli, P., Mariniello, L., Crosa, G., Ortis, M., Occhipinti Ambrogi, A. \& D'Amelio, S. Populations of Acanthocephalus anguillae and Pomphorhynchus laevis in rivers with different pollution levels

Hosseini, S.H. \& Eslami, A. Morphological and developmental characteristics of Echinococcus granulosus derived from sheep, cattle and camels in Iran

Mendoza de Gives, P., Flores Crespo, J., Herrera Rodriguez, D., Vazquez Prats, V., Liebano Hernandez, E. \& Ontiveros Fernandez, G.E. Biological control of Haemonchus contortus infective larvae in ovine faeces by administering an oral suspension of Duddingtonia flagrans chlamydospores to sheep.

Nakaya, K., Oomori, Y., Kutsumi, H. \& Nakao, M. Morphological changes of larval Echinococcus multilocularis in mice treated with albendazole or mebendazole.

\section{Research Notes}

Albrecht, B.K., Fried, B. \& Sherma, J. Effects of Echinostoma caproni infection on the phospholipid and sphingolipid content of the intestinal mucosa of ICR mice

Harnnoi, T., Wijit, A., Morakote, N., Pipitgool, V. \& Maleewong, W. Specific gravity of Opisthorchis viverrini eggs

Index of Authors (Volume 72).

All rights reserved. No part of this publication may be reproduced, in any form or by any means, electronically, mechanically, by photocopying, recording or otherwise, without prior permission of the copyright owner. 